\title{
Aquatic macrophyte Spirodela polyrrhiza as a phytoremediation tool in polluted wetland water from Eloor, Ernakulam District, Kerala.
}

\author{
Anil Loveson, Rajathy Sivalingam and Syamkumar R. \\ School of Environmental Studies, Cochin University Of Science and Technology
}

\begin{abstract}
This study involved a laboratory experiment on the efficiency of the plant duckweed Spirodela polyrrhiza in improving the quality of two polluted wetlands of Eloor industrial area, Ernakulam, Kerala. The efficiency was tested by measuring some of physicochemical characteristics of the control and plant treatments after each eight days. All the parameters show considerable rate of reduction. In wetland I, The highest rates of reduction after 8 days of treatment were for heavy metals, accounting 95\%, 79\%, and 66\% for Lead, Copper and Zinc, respectively, followed by 53\% for Chromium, 45\% for Mercury, 26\% for Cobalt, $20 \%$ for manganese and $7 \%$ for Nickel. Other factors like pH, BOD, COD, Nitrate, Phosphate, sulphate, TDS, TSS and Turbidity reduced by $12 \%, 37 \%, 49 \%, 100 \%, 36 \%, 16 \%, 53 \%, 85 \%$ and $52 \%$ respectively. In wetland II also heavy metals were removed with $\mathrm{Cd}(100 \%), \mathrm{Fe}(98 \%), \mathrm{Pb}(91 \%), \mathrm{Cu}(74 \%) \mathrm{Zn}(62 \%)$ and $\mathrm{Hg}(53 \%)$ removed more efficiently. The results showed that this aquatic plant can be successfully used for wastewater pollutants removal. Other physiochemical parameters like pH, BOD, COD, Nitrate, Phosphate, sulphate, TDS, TSS and Turbidity reduced by $14 \%, 40 \%, 60 \%, 100 \%, 38 \%, 65 \%, 73 \%, 85 \%$, and $51 \%$ after 8 days of treatment.
\end{abstract}

Key words: Phytoremediation, Spirodela polyrrhiza, Lemnaceae, Wetland, Heavy metals

\section{Introduction}

Wetlands support a wide array of flora and fauna and deliver many ecological, climatic and societal functions. Scientists often refer to wetlands as the" kidneys" of the earth. . Kerala is well known for its wetlands.

Eloor, an island of $11.21 \mathrm{sq} / \mathrm{km}$, on the Periyar River is home to more than 247 chemical industries and large number of wetlands. The soil, water bodies and the wetlands in and around Eloor have been contaminated with heavy metals. Duckweed based wastewater systems are promising to be used in effluent treatment considering organic matter, pathogen and nutrient removal (Smith and Moelyowati 2001). Besides, duckweeds are floater plants, which reduce suspended solids by blocking light penetration. Thus, light availability causes algae die off, which settle or disintegrate. Ran et al. (2004) points the advantages of using duckweeds due to its high production rate, easy manual harvest from the surface, high protein and low fiber content The aim of the present investigation was to evaluate the effectiveness of duckweed Spirodela polyrrhiza to remove all impurities as well as heavy metals from the water samples taken from two sites of polluted welands in Eloor. Among macrophytes, duckweeds are very small floating aquatic macrophytes belonging to the Lemnaceae family which grow on the nutrient rich surface and in fresh waters and they are known for their efficiency in nutrient uptake (Bal-Krishna and Polprasert, 2008). Likewise, Lemnaceae have the greatest capacity in organic matter removal and in absorbing the micro-elements such as potassium, calcium, sodium and magnesium among others. However, duckweed plants grow only in the upper water surface layer where mainly pollutant removal takes place (Dalu and Ndamba, 2003). In India phytoremediation techniques are on initial scale and detail investigations are necessary for further research.

\section{Sample collection}

\section{Materials and methods}

One sample (Wetland 1) was collected approximately 8 metres north of the Kuzhikundam Thodu creek, at a location approximately $10 \mathrm{~m}$ northwest of the HIL site boundary ( Lat $10^{\circ} 04^{\prime} 51.76^{\prime \prime} \mathrm{N}$ and Long $76^{\circ}$ 17'32.55”E) . ( see table 1) The second sample ( Wetland 2) was collected from the wetlands southwest of the "Amanthuruthu" wetland area, approximately 150 metres west of the HIL ( Hindustan Insecticides Limited) site, and approximately 80 metres south of the Kuzhikundam Thodu creek ( Lat $10^{\circ} 04^{\prime} 48.13^{\prime \prime} \mathrm{N}$ Long $76^{\circ}$

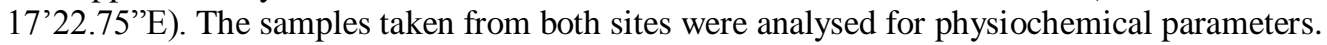

\section{Duckweed treatment system}

Spirodela polyrhiza is a floating aquatic macrophyte belonging to the family Lemnaceae and can be found worldwide on the surface of fresh and brackish waters (Zimmo, 2003). The Lemna and Spirodela are among the most standardized test organisms in aquatic ecotoxicology (EPA 1996; DIN2000, 2001; Eberius 
2001; OECD 2002). The wetland water collected had undergone preliminary sieving step to get rid of large suspended solids. The transferred water was immediately collected into the aquariums in laboratory conditions (as replicates). The treatment system with growing duckweed in three small glass aquariums (length 18 inches) was constructed in laboratory set up .Each aquarium was 10 inches deep and 9 inches wide. These aquariums were arranged in such a way that light availability is maximum. The sides were covered to prevent light entering except at the top (Parr et al., 2002),. Duckweed (Spirodela polyrhiza.) plants were collected from an unpolluted natural pond near Fort Kochi, Kerala .The stocks were cleaned by tap water then washed by distilled water . .

Approximately $50 \mathrm{~g}$ of fresh, wet Spirodela polyrrhiza plants were stocked into each of the three aquariums. Each aquarium was supplied sequentially with wetland water diluted with distilled water in 1:4 ratios. Each of the three aquariums was filled with same dilutions of wetland water. An aquarium is kept with same dilution but without macrophyte is considered as control. The experiment was kept under laboratory conditions of temperature $(25+2)$ and lighting ( 8 light: 16 dark). Detention time of duckweed was 8 days in the first reactor, 4 days and 2 days in the second and third one. After harvesting, new and prewashed duckweed was inserted. Water volume reduction by volatilization was compensated by addition of pure water.

\section{Analytical methods}

A single sample collection has been done from the study area. The water collected from the site was analysed for physio chemical characteristics. The parameters of study are pH, BOD, COD, Nitrate, Phosphate, Sulphate,TDS, TSS and Turbidity before and three weeks after the experiment. Analysis revealed that wetland water is a cocktail of variety of metals including heavy metals. Metals like Copper, Lead, Zinc, Chromium, Cobalt, Manganese, Mercury and Nickel were present .

During the treatment process subsurface (under duckweed mat) water samples for physico-chemical, were collected in polyethylene bottles from all sides of each tank and then mixed. This procedure carried out every week. Initial and final measurements after three weeks of exposure were made. The percentage of removal or removal efficiency was also calculated. Physico-chemical analysis were carried out according to standard methods for examination of water and wastewater (APHA, 1992). Field parameters were measured in situ. The statistical analysis was done using STATISTICA software.

\section{Results and Discussion}

The results of efficiency of Spirodela in scavenging contaminants indicate that the presence of this macrophyte was an important element for contaminant removal in wastewater. Hydrophytes can supply required oxygen by oxygen leakage from the roots into the rhizosphere to accelerate aerobic degradation of organic compounds in wetlands. This assumption was confirmed in the present study, since the accumulation of heavy metals were higher in plants than water. Rhziofiltration, also referred to as phytofiltration, is based on hydroponically grown plants that have shown to be most efficient in removing heavy metals from water (Raskin et al., 1994).

In physio-chemical analysis different parameters (colour, $\mathrm{pH}, \mathrm{BOD}, \mathrm{COD}$, Nitrate, Phosphate , Sulphate total dissolved solids, TSS and turbidity of wetland I and II were studied . During sample collection colour of the wastewater samples was turbid or slightly yellowish. The level of colour in the wastewater may be due to the presence of total dissolved solids.

The $\mathrm{pH}$ of water from wetland I was alkaline 8.2 and for wetland II was 8.4 were found to be in the optimum range for duckweed growth(Dalu \& Ndamba, 2002). After 2 days of treatment it has reduce to 7.2 and 7.9 for WI and WII. In the remaining two treatment chambers the $\mathrm{pH}$ remains 7.2 and 7.4 respectively after 4days and 7.2 for both samples after 8 days of treatment (Figure 1\&2) In the present experiment temperature ranged between $21.7^{\circ} \mathrm{C}$ and $23^{\circ} \mathrm{C}$ which was within temperature tolerance limit for duckweed growth as mentioned by Culley et al., (1981) who found that the upper temperature tolerance limit for duckweed growth was around 34oC. Duckweed tolerance allows it to be used for year-round wastewater treatment in areas where tropical macrophytes, such as water hyacinths, can only grow in summer (Cheng et al., 2002). 
Figure I: Physiochemical parameters of wetland I measured after 2,4 and 8 days of treatment using duckweed Spirodela polyrrhiza:

\begin{tabular}{|l|l|l|l|l|l|l|l|}
\hline $\begin{array}{c}\text { Physiochemical } \\
\text { parametrs }\end{array}$ & $\begin{array}{c}\text { Before } \\
\text { treatment }\end{array}$ & $\begin{array}{c}\text { After 2 } \\
\text { days of } \\
\text { treatment }\end{array}$ & $\begin{array}{c}\text { Removal } \\
\text { efficiency }\end{array}$ & $\begin{array}{c}\text { After 4 } \\
\text { days of } \\
\text { treatment }\end{array}$ & $\begin{array}{c}\text { Removal } \\
\text { efficiency }\end{array}$ & $\begin{array}{c}\text { After 8 } \\
\text { days of } \\
\text { treatment }\end{array}$ & $\begin{array}{c}\text { Removal } \\
\text { efficiency }\end{array}$ \\
\hline PH & 8.2 & 7.42 & 10 & 7.34 & 10.4 & 7.2 & 12.1 \\
\hline BOD (mg/L) & 110 & 96 & 13 & 87 & 21 & 69 & 37.2 \\
\hline COD( mg/L) & 320 & 196 & 39 & 178 & 44.3 & 162 & 49.3 \\
\hline Nitrate( mcg/L) & 27 & 15 & 46 & 4.3 & 84.0 & 0 & 100 \\
\hline Phosphate(mcg/L) & 11 & 9.2 & 16.36 & 8.2 & 25.4 & 7 & 36.3 \\
\hline Sulphate(mg/L) & 500.12 & 469 & 6.30 & 444.2 & 11.1 & 421 & 16 \\
\hline TDS (mg/L) & 3210.3 & 3111 & 3.09 & 2928.11 & 9 & 1522 & 53 \\
\hline TSS (mg/L) & 218.41 & 99 & 55 & 65.12 & 70.1 & 32 & 85.4 \\
\hline Turbidity( NTU) & 29 & 22.4 & 23 & 19.7 & 32.06 & 14 & 52 \\
\hline Copper( mcg/L) & 65 & 28.22 & 57 & 21.56 & 67 & 14 & 79 \\
\hline Lead( mcg/L) & 26 & 17.31 & 33.4 & 9.43 & 64 & 1.3 & 95 \\
\hline Zinc( mcg/L) & 212 & 177.21 & 16.4 & 92.4 & 56.4 & 72.3 & 66 \\
\hline Chromium(mcg/L) & 118 & 101.23 & 14.2 & 82 & 31 & 56 & 53 \\
\hline Cobalt( mcg/L) & 7.2 & 6.4 & 11.1 & 5.2 & 28 & 5.2 & 28 \\
\hline Manganese(mcg/L) & 8 & 8 & 5 & 7.2 & 10 & 6.4 & 20 \\
\hline Mercury( mcg/L) & 2 & 2 & 0 & 1.8 & 10 & 1.1 & 45 \\
\hline Nickel( mcg/L) & 19.3 & 19.1 & 1.03 & 19 & 4 & 18 & 9 \\
\hline
\end{tabular}

Figure II: Physiochemical parameters of wetland II measured after 2,4 and 8 days of treatment using duckweed Spirodela polyrrhiza:

\begin{tabular}{|c|c|c|c|c|c|c|c|}
\hline $\begin{array}{c}\text { Physiochemical } \\
\text { parameters }\end{array}$ & $\begin{array}{c}\text { Before } \\
\text { treatment }\end{array}$ & $\begin{array}{c}\text { After } 2 \\
\text { days of } \\
\text { treatment }\end{array}$ & $\begin{array}{l}\text { Removal } \\
\text { efficiency }\end{array}$ & $\begin{array}{c}\text { After } 4 \\
\text { days of } \\
\text { treatment }\end{array}$ & $\begin{array}{l}\text { Removal } \\
\text { efficiency }\end{array}$ & $\begin{array}{c}\text { After } 8 \\
\text { days of } \\
\text { treatment }\end{array}$ & $\begin{array}{l}\text { Removal } \\
\text { efficiency }\end{array}$ \\
\hline $\mathrm{PH}$ & 8.4 & 8 & 6.0 & 7.4 & 12 & 7.2 & 14.2 \\
\hline $\mathrm{BOD}(\mathrm{mg} / \mathrm{L})$ & 341 & 292.1 & 14.3 & 271.2 & 20.4 & 205.1 & 40.0 \\
\hline $\mathrm{COD}(\mathrm{mg} / \mathrm{L})$ & 679 & 511.2 & 25.0 & 464.4 & 32.0 & 268.3 & 60.4 \\
\hline Nitrate $(\mathrm{mcg} / \mathrm{L})$ & 12.0 & 6.1 & 48.0 & 1.1 & 91.0 & 0 & 100 \\
\hline Phosphate( mcg/L) & 13.1 & 12.0 & 10.0 & 10.4 & 21.0 & 8.1 & 38.0 \\
\hline Sulphate(mg/L) & 133.0 & 15.0 & 89.04 & 27.4 & 79.3 & 46.2 & 65.1 \\
\hline TDS (mg/L) & 593.1 & 477.0 & 20.0 & 266.3 & 55.1 & 158 & 73.3 \\
\hline TSS (mg/L) & 359 & 181 & 50.0 & 126.0 & 65.0 & 53.0 & 85.2 \\
\hline Turbidity( NTU) & 382 & 286 & 25.1 & 262 & 31.4 & 189 & 51.0 \\
\hline Copper( mcg/L) & 63.3 & 36.0 & 44.0 & 22.0 & 66.0 & 16.4 & 74 \\
\hline Lead( mcg/L) & 34.4 & 23.0 & 34.0 & 13.0 & 63.0 & 3.0 & 91 \\
\hline Zinc( mcg/L) & 301 & 258 & 14.2 & 144.2 & 52.0 & 113.1 & 62.4 \\
\hline Chromium( mcg/L) & 121 & 105.3 & 13.0 & 85.0 & 30 & 62.3 & 49.0 \\
\hline Cobalt $(\mathrm{mcg} / \mathrm{L})$ & 8 & 7.2 & 10 & 6.3 & 21.2 & 5.0 & 40 \\
\hline Manganese ( mcg/L) & 7.3 & 7.1 & 3.0 & 6.4 & 12.3 & 5.1 & 30.1 \\
\hline Mercury $(\mathrm{mcg} / \mathrm{L})$ & 3.4 & 3.1 & 9.0 & 3.0 & 18.0 & 2.0 & 53.0 \\
\hline Nickel( mcg/L) & 22.3 & 21 & 6.0 & 18.1 & 19.0 & 18.0 & 22.0 \\
\hline $\operatorname{Iron}(\mathrm{mg} / \mathrm{L})$ & 5.3 & 5.1 & 4.0 & 4.2 & 21.0 & 0.1 & 98.1 \\
\hline Cadmium( mg/L) & 3 & 3 & 0 & 3.0 & 7.0 & 0 & 100 \\
\hline
\end{tabular}

Turbidity was reduced by $23 \%$ from 29 NTU to 22.4 NTU after 2 days for WI. It further reduced to 19.7( $32 \%$ ) after 4 days of treatment . After 8 days it was 13.8 NTU which means almost half of the turbidity has been removed Fig (1) .In WII turbidity was reduced by $25.13 \%$ from 382 NTU to 286 NTU after 2 days. It further reduced to 262 (31.4) and to $189 \mathrm{NTU}(50.5 \%)$ after 4 days and 8 days of treatment respectively( Fig:10).

This may be attributed to decrease the concentration of suspended material because of settlement on the bottom and adsorption on aquarium glass and this was shown in statistical analysis, as it recorded significant correlation between suspended solids and turbidity $(r=0.94 ; p<0.05)$. 
Figure: 3

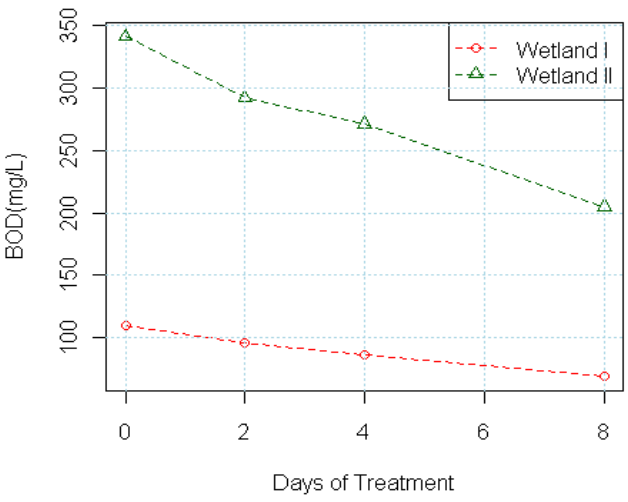

Figure: 5

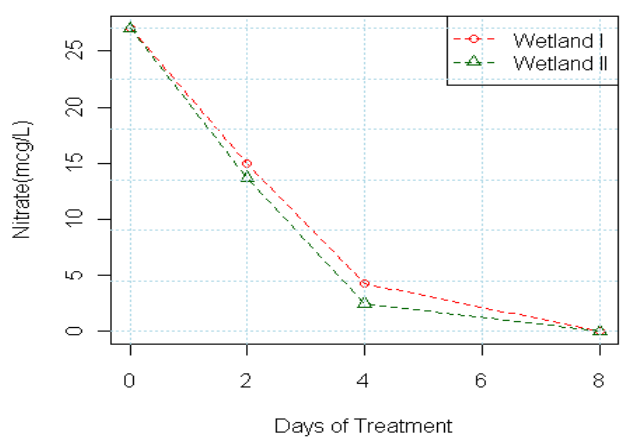

Figure: 7

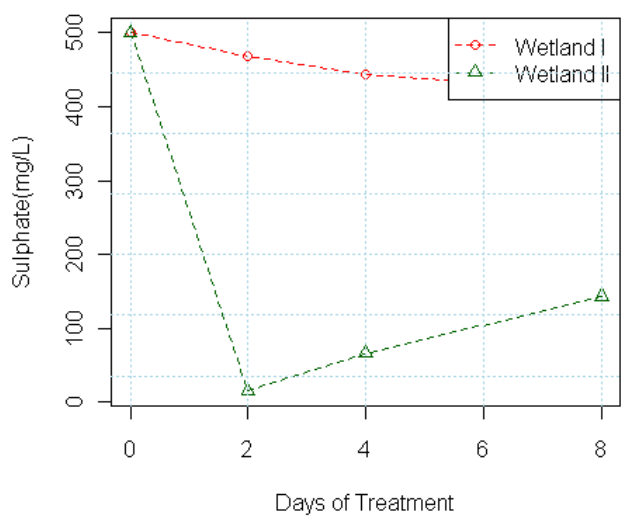

Figure: 9

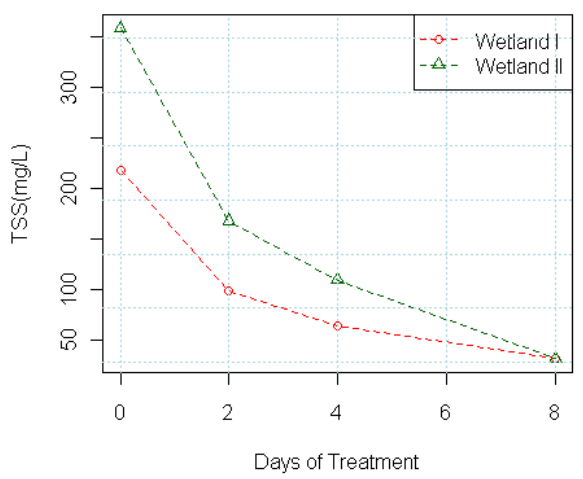

Figure: 4

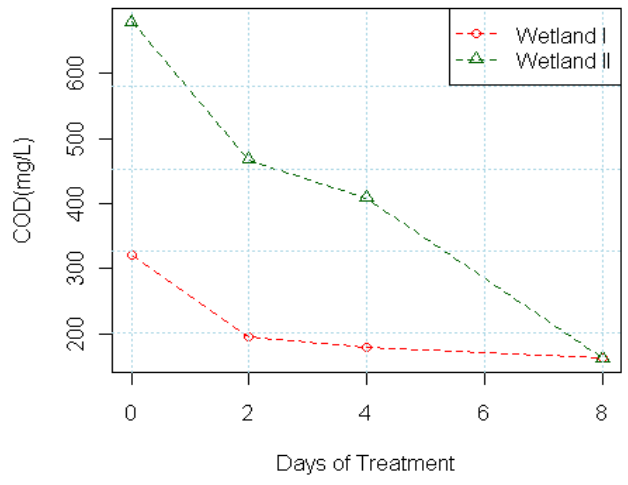

Figure: 6

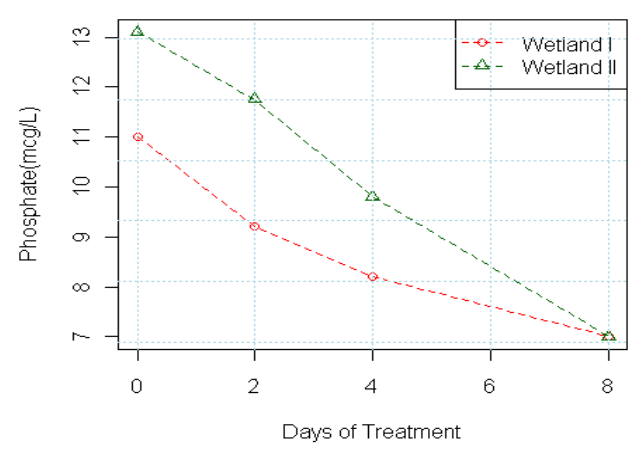

Figure: 8

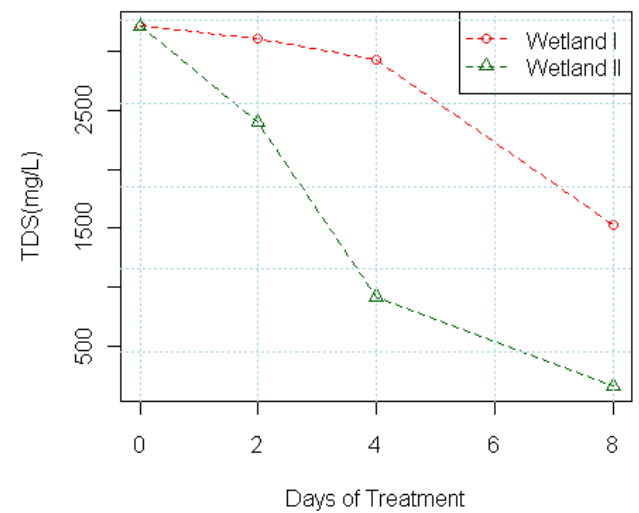

Figure: 10

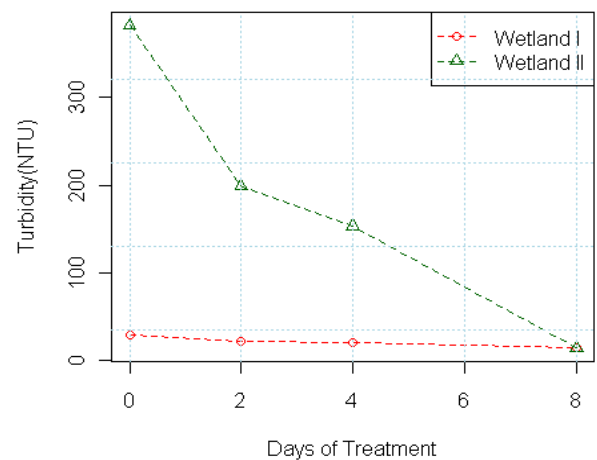


Figure: 11

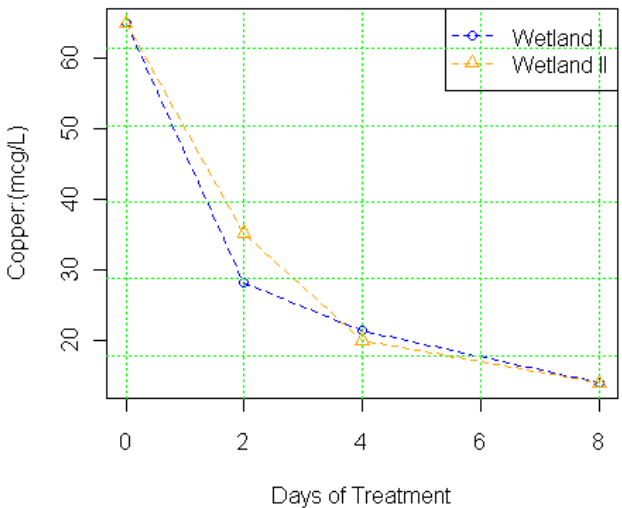

Figure:13

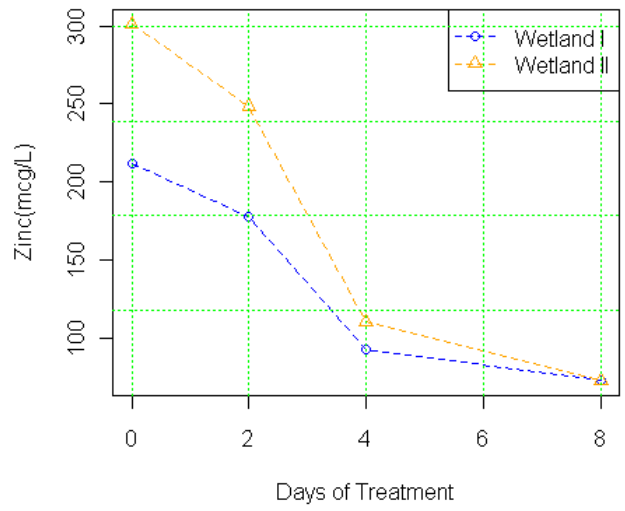

Figure: 15

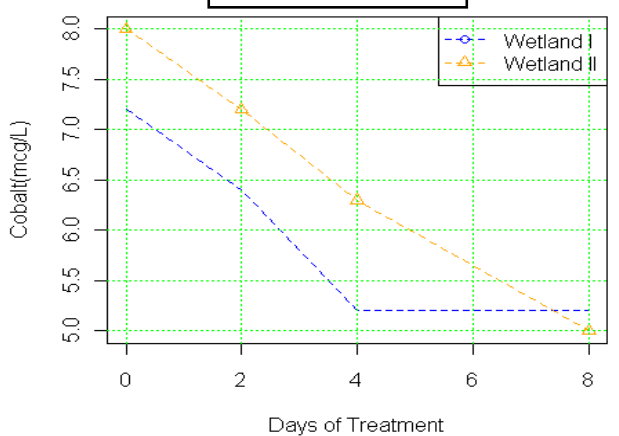

Figure: 17

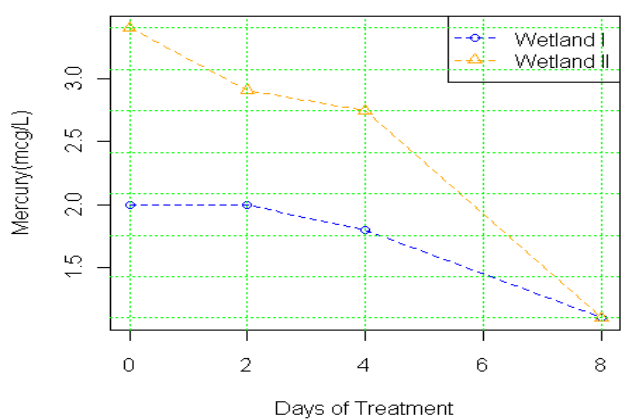

Figure: 12

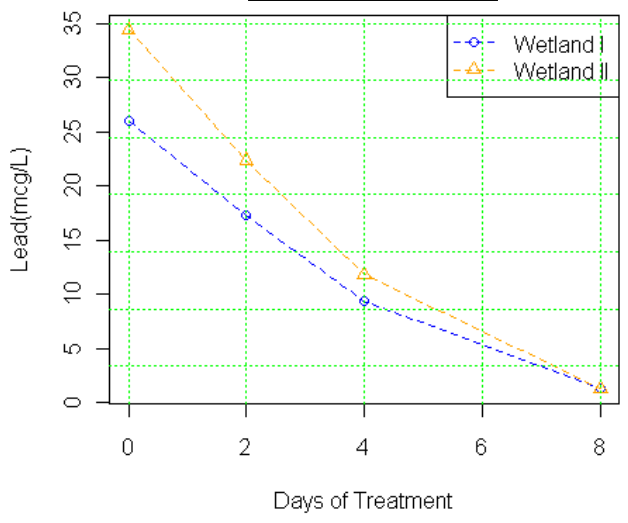

Figure: 14

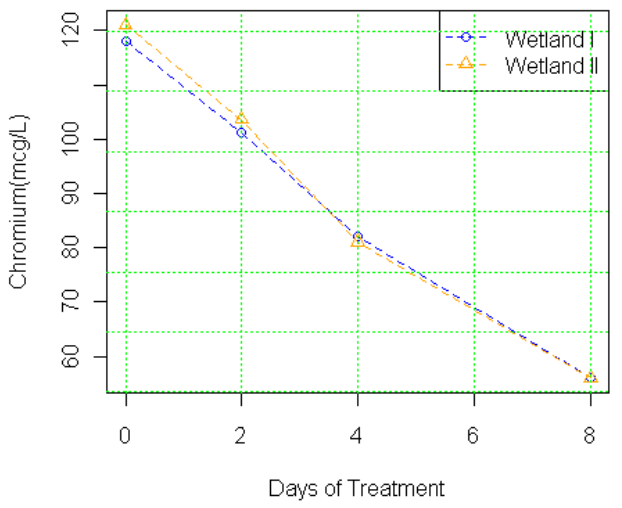

Figure: 16

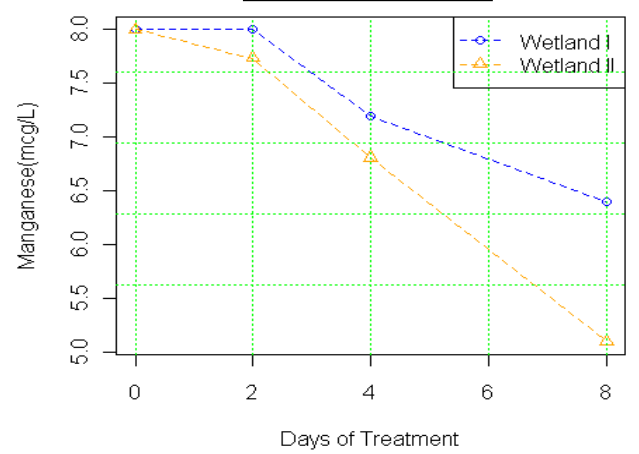

Figure: 18

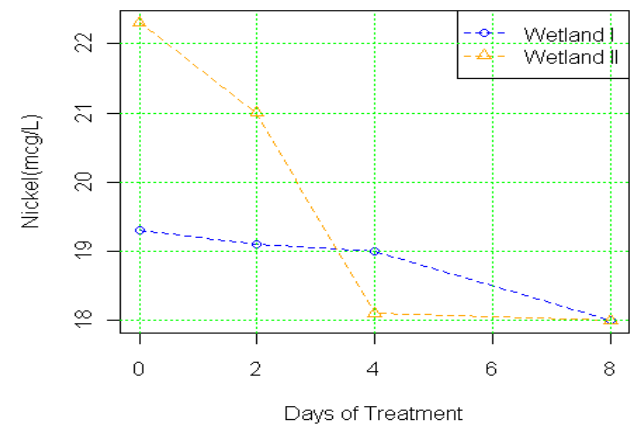


Figure: 19

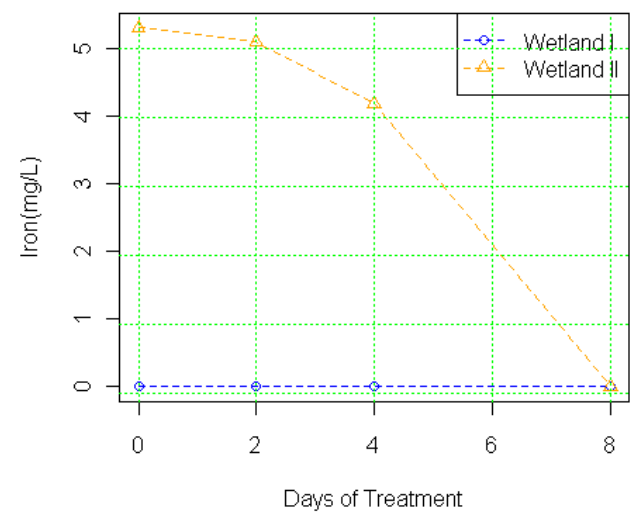

Figure: 20

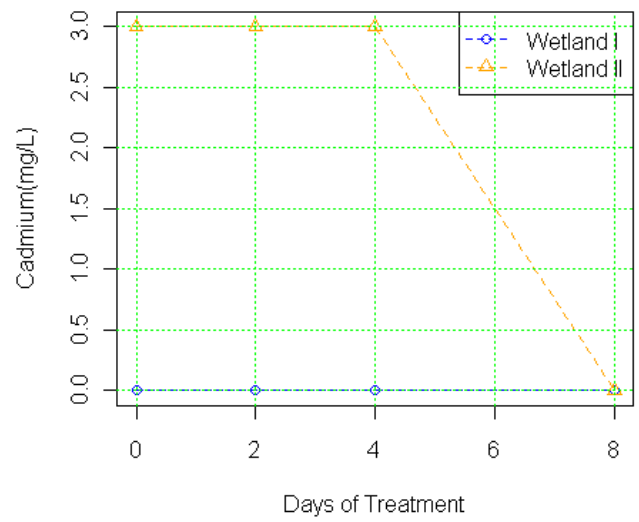

Figure : 9 shows total suspended solids (TSS) values decreased by increasing treatment periods, showing maximum concentration of 218.4 and 359 for WI and WII respectively before treatment. The concentration sides down to 98.66 and $181 \mathrm{mg} . \mathrm{L}-1$ after 2 days (55\% and $49.5 \%$ respectively) and further reduced to $65.12 \mathrm{mg} / \mathrm{L}(70.1 \%)$ and 125.6 ( 65.01\%)after 4 days and finally decreased by $85.4 \%$ and $85.2 \%$ $(31.7 \mathrm{mg} / \mathrm{L}$ and $52.8 \mathrm{mg} / \mathrm{L}$ respectively) which corroborates the findings of Pandy, M.(2001) regarding discharged duckweed treatment system in Halisahar ,Likewise Huang, P.,Han,B and Lin,Z.(2007) record a clear reduction in resuspension of sediment in Taiho lake during 41 days which covered by floating aquatic plants , and this result agreed with the study of Al-Sabunji, A.A. and AlMarashi, A.M.(2002).

It was also revealed that total dissolved solids (TDS) of WI and WII recorded their minimum values of $1522 \mathrm{mg} / \mathrm{L}(52.5 \%$ ) and $158 \mathrm{mg} / \mathrm{L}(73.3 \%$ ) after 8 days treatment. It was $3111 \mathrm{mg} / \mathrm{L}$ ( $3 \%$ reduction)and 476.5 $\mathrm{mg} / \mathrm{L}(19.6 \%$ reduction) after 2 days of treatment .It was $2928.11 \mathrm{mg} / \mathrm{L}(8.7 \%$ reduction $)$ and $266.3 \mathrm{mg} / \mathrm{L}$ (55.10\%) after 4 days. Majority of TDS was reduced between 4 days to 8 days of treatment. This decrease was due to the plant capacity to take some organic and inorganic ions ( Figure: 8).

Results in Figure (1and 2) shows that sulfate concentration in WI and WII recorded by $6.3 \%$ and $89.04 \%$ as reduction percentage during 2 days, $11.18 \%$ and $79.33 \%$ during 4 days and $15.8 \%$ and $65.15 \%$ after 8 days of Phytoremediation ( Figure: 7). The cause of reduction may be due to plant ability to absorb different types of pollutants and accumulated in their tissues Mkandawire, M. and Dudel, E.G.(2007). But the sulphate reduction percentage after 8 days of treatment is found to be insufficient. It may be assumed that Spirodela polyrhiza is a poor tool for phytoremediation of sulphate from waste water. The phosphate content from the wetland water I and II were $11 \mathrm{mcg} / \mathrm{L}$ and $11.71 \mathrm{mcg} / \mathrm{L}$ respectively. After 2 days of treatment ,it has been reduced by $16.3 \%$ and $47.9 \%$ and after 4 days it has been reduced by $25.4 \%$ and $20.61 \%$ respectively.

After 8 days it has been reduced by $36.36 \%$ to $7.0 \mathrm{mcg} / \mathrm{L}$ for WI and reduced by $37.6 \%$ to 8.17 after 8 days of growth (Figure:7).. The removal of phosphate is comparatively better than sulphate. Similarly Nitrate content was $27 \mathrm{mcg} / \mathrm{L}$ for WI and $11.71 \mathrm{mcg} / \mathrm{L}$ for WII. It has been reduced to $14.7 \mathrm{mcg} / \mathrm{L}(45.55 \%)$ and 6.1 $\mathrm{mcg} / \mathrm{L}(47.9 \%)$ respectively with 2 days of treatment. It was further down to mere $4.3 \mathrm{mcg} / \mathrm{L}$ and $1.1 \mathrm{mcg} / \mathrm{L}$ after 4 days ( $84 \%$ and $90.6 \%$ respectively). Eight days of treatment was enough to remove nitrate from the water completely from both samples (100\%) See Figure:5.

Figure I and 2 also reveals the gradual reduction of factor like BOD, COD, Phosphate, Nitrate etc. with time. Data revealed that Spirodela polyrhiza mat effectively reduced BOD by $12.7 \%$ for WI and $14.34 \%$ for WII (reduced from $110 \mathrm{mg} \mathrm{O} 2 \mathrm{~L}-1$ at zero days reaching $96 \mathrm{mg} \mathrm{O} 2 \mathrm{~L}-1$ for WI and reduced from $341 \mathrm{mg} \mathrm{O} 2 \mathrm{~L}-1$ at zero days reaching $292.1 \mathrm{mg} \mathrm{O} 2 \mathrm{~L}-1$ 2days treatment). After 4 days it further reduced by $20.9 \%$ (reduced to 87 $\mathrm{mg} / \mathrm{L}$ ) and $20.46 \%$ (reduced to $271.2 \mathrm{mg} / \mathrm{L}$ ) for WI and WII respectively. After 8 days BOD stands at $69 \mathrm{mg} / \mathrm{L}$ (reduced by $37 \%$ ) for WI and stands at $205.1 \mathrm{mg} / \mathrm{L}$ ( reduced by 39.85\%) for WII. Zimmo et al. (2005) found that BOD removal efficiency was higher in duckweed based ponds than in algae based ponds. Pandey (2001) reported that in Delhi the duckweed ponds were operated at different flow rates giving hydraulic retention time from 5.4 to 22 days, a $30-50 \%$ reduction in phosphate, 56 - 80\% reduction in ammoniacal nitrogen and 66 $80 \%$ reduction in BOD (Figure:3). In concurrence with the present findings, Oron et al. (1988) mentioned that the duckweed contribution for the removal of organic material is due to their ability to direct use of simple organic compounds. The COD has been reduced by $38.75 \%$ for WI and $24.71 \%$ immediately after 2 days of phytoremediation (reduced from the initial concentration of $320 \mathrm{mg} / \mathrm{L}$ to $196 \mathrm{mg} / \mathrm{L}$ and $679 \mathrm{mg} / \mathrm{L}$ to 511.2 $\mathrm{mg} / \mathrm{L}$ ). After 4 days it further reduced by $44.37 \%$ ( reduced to $178 \mathrm{mg} / \mathrm{L}$ ) for $\mathrm{WI}$ and reduced by $31.60 \%$ ( reduced to $464.4 \mathrm{mg} / \mathrm{L}$ ) and finally after 8 days, reduced to mere $162 \mathrm{mg} / \mathrm{L}(49.375 \%)$ for WI and reduced to 
$268.3 \mathrm{mg} / \mathrm{L}$ (60.4\%) for WII (Figure: 4). Korner et al. (1998) mentioned that duckweed significantly enhanced COD removal in shallow batch systems. Pandey (2001) reported that COD removal was in the range of 70\% $80 \%$ in the discharged duckweed treatment system at Halisahar. However in the present study, the COD and BOD removal by the macrophyte were not up to the capacity of Lemna minor.

Ferrara et al. (1985) indicated the reliability of wastewater treatment by some aquatic plants including duckweed in adsorption of the heavy metals cadmium and zirconium. Viet et al. (1988) reported that duckweed plants proved to be an excellent bioaccumulator of various heavy metals, which allowed it to treat a variety of wastewaters including industrial and highly polluted wastes. Hammouda et al. (1995) evaluated the efficiency of duckweed aquatic treatment in heavy metals removal in various water systems data obtained suggested a maximum reliability of systems with mixtures containing high ratios of wastewater. In the present study metals like Copper, Lead, Zinc, Chromium, Cobalt, Manganese, Mercury and Nickel were found in the wetland water and removed by the plant by greater extend. The eight metals studied, showed $\mathrm{Pb}>\mathrm{Cu}>\mathrm{Zn}>\mathrm{Cr}>\mathrm{Hg}>\mathrm{Co}>\mathrm{Mn}>\mathrm{Ni}$ pattern of absorbance. $\mathrm{Pb}$ concentration was $26 \mathrm{mcg} / \mathrm{L}$ in the control solution. After 2 days of treatment it has been reduced by $33.4 \%$ to $17.3 \mathrm{mcg} / \mathrm{L}$. After 4 days it further reduced by $63.7 \%$ to $9.43 \mathrm{mcg} / \mathrm{L}$. Finally after 8 days Lead concentration is only $1.3 \mathrm{mcg} / \mathrm{L}$, which means $95 \%$ removal (Figure: 12). After 8 days of treatment Copper content in the water has been removed by $78.76 \%$ which means a reduction from initial concentration of $65 \mathrm{mcg} / \mathrm{L}$ to final concentration of $13.8 \mathrm{mcg} / \mathrm{L}$ ( Figure: 11 ). Copper shows removal by $56 \%$ after 2 days and removal by $66.83 \%$ after 4 days of treatment with Spirodela polyrhiza plant. Initial concentration of Zn was $212 \mathrm{mcg} / \mathrm{L}$. Two days of treatment is only enough to remove $16.4 \%$ of $\mathrm{Zn}$ from the wetland water which means reduction to $177.21 \mathrm{mcg} / \mathrm{L}$. Four days of treatment was enough to remove $56.4 \%$ of $\mathrm{Zn}$ ( reduced to $92.4 \mathrm{mcg} / \mathrm{L}$ ) See Figure: 13. Chromium concentration was $118 \mathrm{mcg} / \mathrm{L}$ before treatment. It has been reduced by $14.21 \%$, $30.71 \%$ and $52.5 \%$ after 2, 4 and 8 days of treatment (Figure:14). Cobalt concentration was very low initially i.e. $7.2 \mathrm{mcg} / \mathrm{L}$. After 2 days it has been reduced by mere $11.11 \%$. After 4 days the concentration was measured as $5.2 \mathrm{mcg} / \mathrm{L}$ i.e. $27.77 \%$. Interestingly even after 8 days of treatment the cobalt concentration did not came down any further i.e. it remains at $27.77 \%$ removal ( Figure:15). The Manganese concentration has been reduced by $20 \%$ from $8 \mathrm{mcg} / \mathrm{L}$ to just $6.4 \mathrm{mcg} / \mathrm{L}$ even after 8 days of treatment. This reveals that Spirodela polyrhiza is a poor accumulator of Manganese ( Figure: 16). Mercury concentration remains the same even after 2 days of treatment i.e. $2.0 \mathrm{mcg} / \mathrm{L}$. The concentration reduced to $1.1 \mathrm{mcg} / \mathrm{L}$ after 8 days of treatment with the removal efficiency of $45 \%$ (Figure: 17). Nickel shows the least removal after the treatment regime of 8 days. It has been reduced from $19.3 \mathrm{mcg} / \mathrm{L}$ to $17.6 \mathrm{mcg} / \mathrm{L}$ with removal efficiency of just $8.80 \%$ that shows that Spirodela is a poor accumulator of Nickel( Figure: 18). Iron and Cadmium were present in Wetland II but were absent in wetland I. Fe were removed $98.1 \%$ and Cd removed completely (100\%) after 8 days of treatment ( Figure 19\&20).

\section{Conclusion}

In the current study macrophyte duckweed Spirodela polyrhiza was employed as effective phytoremediation agent in the polluted wetland water from Eloor. Constructed wetlands with Spirodela mat may help to prevent the spread of heavy metal contamination from land to the aquatic environment. High metal removal rates of close to $100 \%$ have been reported in both wetlands is quite promising. The advantage of lagoon treatment systems that use aquatic plants as productive 'sinks' for wastewater nutrients from a wide range of sources. It is easy and cheap to construct and operate suggests they are a suitable alternative for wastewater purification.

\section{Acknowledgement}

This study was carried out with the help of School of Environmental Studies, Cochin University of Science and Technology, Kochi, Kerala.

\section{References}

[1]. Al-Sabunji,A.A. and AlMarashi, A.M.(2002). Use the reed in treatment sewage water. ww.ieps.info/front

[2]. American Public Health Association "APHA", 1992. Standard Methods for the Examination of Water and Wastewater, 18th edition. Washington, D.C.

[3]. Cheng, J, Bergmann, B.A., Classen, J.J., Stomp, A.M. and Howard, J.W. (2002) Nutrient recovery from swine lagoon water by Spirodela punctata. Bioresource Technology.81:81-85.

[4]. Culley, D.D. and Epps, E.A. (1973) Use of duckweed for waste treatment and animal feed. Research Journal of the Water pollution Control Federation.45:337-347.

[5]. Dalu, J.M. and J. Ndamba, 2002. Duckweed based wastewater stabilization ponds for wastewater treatment; a low cost technology for small urban areas in Zimbabwe. In: 3rd WaterNet-Warfsa Symposium 'Water Demand Managementfor Sustainable Development'. Dar ElSalaam.

[6]. DIN(2000) Duckweed growth Inhibition test: Determination of the non poisonous effect of water constituent s and waste water to duckweed, Deutsches Institut furcNormung e.V urchBeuth Verlag, Berlin, 19pp.

[7]. Eberius M(2001) Assesment of Inhibition values and comprehensive analysis of biotests. LemnaTec GmbH,Wurselen, online http://www.lemnatec.com/Literatur/LT003.pdf. 
[8]. EPA (1996) Aquatic plant toxicity test using LemnaSpp:Tiers I and II- OPPTS 850.4400.United states Environmental protection Agency Prevention, pesticides and Toxic substances Unit, Newyork,9 pp.

[9]. EPA 1996 Ecological effects test Guidelines OPPTS 850.4400 Aquatic plant toxicity test using lemna ssp., Tiers I and II , EPA 712-C-96-156.

[10]. Ferrara, L., P. Forgione, O. Schettino and V. Rullo, 1985. The use of aquatic plants in wastewater treatment adsorption of zirconium and cadmium. Bollettino Della Societa Italiana Di Biologia Sperimentale, 61: 43-8.

[11]. Hammouda, O. and M.S. Abdel-Hameed, 1994. Response of phytoplankton populations to aquatic treatment by Lemna gibba. Folia Microbiol.,39: 420-7.

[12]. Huang ,P.,Han,B.and Lin,Z.(2007).Floating - Leaved Macrophyte (Trapa quadrispinosa Roxb) Beds have Significant Effects on Sediment Resuspension in LakeTaiho, China. Hydrobiologia.581:189-193.

[13]. KC Balkrishna and C Polprasert (2008) An Integrated Kinetic Model for Organic and Nutrient Removal by Duckweedsbased Wastewater Treatment (DUBWAT) System, Ecological Engineering, 34(3), 243-250.

[14]. Korner, S., G.B. Lyatuu and J.E. Vermaat, 1998. The influence of (Lemna gibba L.) on the degradation of organic materialin duckweed covered domestic waste water. Water Res., 32: 3092-98.

[15]. Mkandawire ,M. and Dudel ,E.G.(2007).Are Lemna spp.Effective Phytoremediation Agents Biorem, Biodiv and Bioaval.1(1)5671.

[16]. OECD, (2002). Guidelines for the testing of chemicals. Lemna Sp. Growth Inhibition Test, Draft guidline 221.

[17]. Oron, G., A. De Vegt and D. Porath, 1988. Nitrogen removal and conversion by duckweed grown on wastewater.Water Res., 22: 179-84.

[18]. Pandey, M., 2001. Duckweed Based Wastewater Treatment. Invention Intelligence.

[19]. Parr, L.B., R.G. Perkins and C.F. Mason, 2002.Reduction in photosynthetic efficiency of Cladophora glomerata, induced by overlying canopies of Lemna spp. Water Res., 36: 1735-42

[20]. Ran, N., M. Agami and G. Oron, 2004. A pilot study of constructed wetlands using duckweed (Lemna gibba L.) for treatment of domestic primary effluent. Water Res., 38: 2241-8.

[21]. Raskin, I., P. B. A. Nanda Kumar, V. Dushenkov and D. E. Salt. 1994. Bioconcentration of heavy metals by plants. Curr. Op. Biol. 5:285-290.

[22]. Smith, M.D. and Moelyowati, I (2001) Duckweed based wastewater treatment (DWWT): design guidelines for hot climates. Water Science and Technology. 43:291-299.

[23]. Viet, N., P. Warren and S. Hancock, 1988. The Lemna technology for wastewater treatment. In: SCE/Etal.

[24]. Environ. Engg. Natl. Conference Vancouver, p: 292.

[25]. Zimmo, O., 2003. Nitrogen transformations and removal mechanisms in algal and duckweed waste stabilization ponds. Ph.D Thesis,International Institute for Infrastructural, Hydraulic and Environmental Engineering, Delft, the Netherlands. 